\title{
Study of anti-free radical action of phytopreparations and their effectiveness on animals
}

\author{
Natalya Yarovan ${ }^{1}$, Elena Bondarenko ${ }^{2}$, Natalya Komissarova ${ }^{1}$, Alexei Sergachev ${ }^{1}$, Natalya Gribanova $^{1}$ \\ ${ }^{1}$ Orel State Agrarian University, 69, General Rodina str., Orel, 302019, Russia \\ ${ }^{2}$ Oryol branch of "Central Scientific and Methodological Veterinary Laboratory", 18, Novosilskoe sh., Orel, 302031, \\ Russia
}

\begin{abstract}
With industrial technologies of animal husbandry, the state of the animal's body is characterized by the presence of metabolic disorders considered as oxidative stress. Currently, in animal husbandry, characterized by stressful content in industrial complexes, the use of adaptogenic drugs is required; however, among their abundance, phytobiotics are the most effective in terms of optimizing metabolic processes. Phytobiotics are herbal preparations that are sources of biologically active substances. The work shows the results of studying anti-free radicals of phytobiotics (nettle, germinated wheat sprouts, clover, licorice, marsh cinquefoil and cranberry) in the POL-AOS model system and the results of the application of the developed method of antioxidant protection for high-yielding cows kept under stressful conditions under industrial dairy management. cattle breeding. The basic mechanism of action of phytopreparations based on nettle, germinated sprouts of wheat, clover, licorice, marsh cinquefoil and cranberry in the correction and prevention of biochemical disorders caused by stress is inhibition of free radical oxidation and activation of endogenous antioxidants.
\end{abstract}

\section{Introduction}

With industrial technologies of animal husbandry, the state of the animal's body is characterized by the presence of metabolic disorders, considered as oxidative stress.

Oxidative stress occurs when there is a disturbance in the oxidative-antioxidant system, while the number of reactive free radicals increases pathologically [21, 23]. The emergence of oxidative stress is caused by the impact of negative factors on the animal's body, such as physical inactivity, hypoxia, alimentary stress, lack of insolation, vaccination, etc.

Currently, in animal husbandry, characterized by stressful content in industrial complexes, the use of adaptogenic drugs is required, however, among their abundance, phytobiotics are the most effective in terms of optimizing metabolic processes. Phytobiotics are herbal preparations that are sources of biologically active substances [5]. With the industrial technology of livestock farming, cows do not have free range, which prevents their sufficient supply of green fodder, and, consequently, organic vitamins.

The aim of this work was to study anti-free radicals of phytobiotics (nettle, germinated wheat sprouts, clover, licorice, marsh cinquefoil and cranberry) in the POLAOS model system and to develop antioxidant protection methods for high-yielding cows kept under stressful conditions during industrial dairy farming.

\section{Materials and methods}

The study of the anti-free radical activity of phytopreparations was carried out in the modular system POL-AOS.

The influence of phytobiotics on the body of lactating cows was carried out in the farms of the Oryol region at 2 enterprises: JSC "AGROINDUSTRIAL COMPLEX" ORLOVSKAYA NIVA" and LLC "MASLOVO".

\section{Results and discussion}

At the first stage of the experiment, the anti-free radical action of phytopreparations was assessed in the POLAOS model system proposed by us (Patent dated 08/12/2014 No. 2013106281 "Method for assessing the antioxidant activity of plant raw materials from marsh cinquefoil").

The study of the anti-free radical action of phytopreparations was carried out according to the indices of malondialdehyde (MDA) when they were added to the model system.

In our system, lecithin obtained from soy processing is used as a source of liposomes. According to V.G.

\footnotetext{
Corresponding author: elenav.bondarenko16@gmail.com
} 
Zaitsev, obtaining liposomes from different raw materials exhibits different antioxidant activity, since it is influenced by the components that make up each raw material. A later introduction of the studied antioxidant into the model system excludes the transformation of its antioxidant properties into prooxidants [13].

The initiation of lipid peroxidation in the model system was carried out only by exposure to temperature at $37{ }^{\circ} \mathrm{C}$ (6 hours) and then keeping at room temperature for 48 hours, which reduces energy costs and the overall cost of the experiment.

Table 1. Evaluation of the anti-free radical action of phytopreparations and their compositions

\begin{tabular}{|l|l|l|}
\hline $\begin{array}{l}\text { Name of } \\
\text { phytopreparations }\end{array}$ & $\begin{array}{l}\text { Before introducing } \\
\text { phytopreparations }\end{array}$ & $\begin{array}{l}\text { After introducing } \\
\text { phytopreparations }\end{array}$ \\
\hline $\begin{array}{l}\text { Cranberry + marsh } \\
\text { cinquefoil }\end{array}$ & 1.06 & 0.69 \\
\hline Clover + Licorice & 1.07 & 0.71 \\
\hline $\begin{array}{l}\text { Nettle + wheat } \\
\text { germ }\end{array}$ & 1.08 & 0.64 \\
\hline
\end{tabular}

Analysis of the MDA level after the introduction of phytopreparations showed that MDA decreased when using the composition of marsh cinquefoil+cranberry by $0.37 \mu \mathrm{mol} / \mathrm{L}$, with clover+licorice by $0.36 \mu \mathrm{mol} / \mathrm{L}$, with nettle+wheat germ by $0.44 \mu \mathrm{mol} / \mathrm{L}$.

At the second stage of the experiment, the effectiveness of the effect of the proposed preparations on the organism of highly productive cows was studied 2 weeks after calving. As an indicator of the effectiveness of their action, the indicators of the oxidative-antioxidant system were analyzed by the content of MDA and ceruloplasmin in the blood.

The experiment was carried out at JSC "AGROINDUSTRIAL COMPLEX "ORLOVSKAYA NIVA" and at LLC "MASLOVO".

At JSC "AGROINDUSTRIAL COMPLEX "ORLOVSKAYA NIVA" 3 groups were created: 1) control, 2) experimental (cows 2 weeks after calving: basic ration $(\mathrm{BR})+$ nettle + lecithin + wheat germ), 3) experimental: RR + clover + licorice). The results of the study are shown in Table 2.
Table 2. Level of MDA and ceruloplasmin in the blood of cows with additional introduction of phytobiotics

\begin{tabular}{|l|l|l|}
\hline Name of phytobiotics & \multicolumn{2}{|l|}{ Investigated indicators } \\
\cline { 2 - 3 } & $\begin{array}{l}\text { MDA } \\
{[\mu \mathrm{mol} / \mathrm{L}]}\end{array}$ & $\begin{array}{l}\text { Ceruloplasmin } \\
{[\mu \mathrm{mol} / \mathrm{L}]}\end{array}$ \\
\hline Control group & $2.11 \pm 0.10$ & $1.66 \pm 0.15$ \\
\hline $\begin{array}{l}\text { Experimental (BR + } \\
\text { nettle + lecithin + } \\
\text { wheat germ) }\end{array}$ & $0.43 \pm 0.05^{* *}$ & $2.74 \pm 0.01^{* * *}$ \\
\hline $\begin{array}{l}\text { Experimental (BR + } \\
\text { clover + licorice) }\end{array}$ & $0.56 \pm 0.04^{* *}$ & $2.50 \pm 0.01^{* *}$ \\
\hline
\end{tabular}

Note: $* \mathrm{P}<0.05 ; * * \mathrm{P}<0.01 ; * * * \mathrm{P}<0.001$ relative to animals of the control group.

During the experiment, the MDA level decreased in the 2nd group by $1.68 \mu \mathrm{mol} / \mathrm{L}$, in the $3 \mathrm{rd}$ by $1.55 \mu \mathrm{mol} / \mathrm{L}$, in the control group the MDA indicators remained at the level of the beginning of the experiment. The activity of ceruloplasmin increased in the 2 nd group by $1.08 \mu \mathrm{mol} / \mathrm{L}$, in the $3 \mathrm{rd}$ by $0.84 \mu \mathrm{mol} / \mathrm{L}$, in the control group the indicators remained at the level of the beginning of the experiment.

At LLC "MASLOVO" 2 groups were created: 1) control, 2) experimental (cows 2 weeks after calving: $\mathrm{BR}+$ marsh cinquefoil + cranberry). The results of the study are presented in table 3 .

Table 3. Level of MDA and ceruloplasmin in the blood of cows with the additional introduction of marsh cinquefoil

\begin{tabular}{|c|c|c|}
\hline \multirow[t]{2}{*}{ Name of phytobiotics } & \multicolumn{2}{|c|}{ Investigated indicators } \\
\hline & $\begin{array}{l}\mathrm{MDA} \\
{[\mu \mathrm{mol} / \mathrm{L}]}\end{array}$ & $\begin{array}{l}\text { Ceruloplasmin } \\
{[\mu \mathrm{mol} / \mathrm{L}]}\end{array}$ \\
\hline Control group & $2.86 \pm 0.11$ & $1.49 \pm 0.03$ \\
\hline 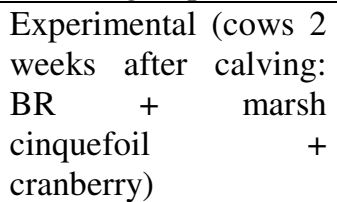 & $0.51 \pm 0.29 * *$ & $2.01 \pm 0.05 * *$ \\
\hline
\end{tabular}

Note: $* \mathrm{P}<0.05 ; * * \mathrm{P}<0.01 ; * * * \mathrm{P}<0.001$ relative to animals of the control group.

Table 4. Hematological indicators of blood of cows with additional introduction of phytobiotics in JSC "AGROINDUSTRIAL COMPLEX "ORLOVSKAYA NIVA"

\begin{tabular}{|c|c|c|c|c|}
\hline Groups & Indicators & Norm & $\begin{array}{c}\text { Before the injectoin of } \\
\text { phytopreparations }\end{array}$ & $\begin{array}{c}\text { After the injection of } \\
\text { phytopreparations }\end{array}$ \\
\hline \multirow{3}{*}{ Control group } & Hemoglobin, g/l & $90-120$ & $106,44 \pm 1,58$ & $10434 \pm 1,15$ \\
\cline { 2 - 5 } & erythrocyte, $10^{12} / 1$ & $5-7,5$ & $5,33 \pm 0,08$ & $5,25 \pm 0,11$ \\
\cline { 2 - 5 } & leukocyte, $10^{9} / 1$ & $6-10$ & $9,72 \pm 0,09$ & $9,81 \pm 0,06$ \\
\hline \multirow{2}{*}{$\begin{array}{c}\text { Experimental (BR }+ \\
\text { nettle + lecithin }+ \\
\text { wheat germ) }\end{array}$} & Hemoglobin, g/l & $90-120$ & $106,66 \pm 1,58$ & $5,47 \pm 0,06^{* *}$ \\
\cline { 2 - 5 } & erythrocyte, $10^{12} / 1$ & $5-7,5$ & $5,11 \pm 0,05$ & $9,54 \pm 0,08^{* *}$ \\
\cline { 2 - 5 } & leukocyte, $10^{9} / 1$ & $6-10$ & $9,42 \pm 0,11$ & $109,60 \pm 1,44^{* *}$ \\
\hline \multirow{2}{*}{$\begin{array}{c}\text { Experimental (BR }+ \\
\text { clover + licorice) }\end{array}$} & Hemoglobin, g/l & $90-120$ & $105,00 \pm 1,55$ & $5,89 \pm 0,07^{* *}$ \\
\cline { 2 - 5 } & erythrocyte, $10^{12} / 1$ & $5-7,5$ & $5,24 \pm 0,10$ & $9,61 \pm 0,06$ \\
\cline { 2 - 5 } & leukocyte, $10^{9} / 1$ & $6-10$ & $9,72 \pm 0,09$ & 1,44 \\
\hline
\end{tabular}

Note: $*_{-} \mathrm{P}<0.05 ; *_{-} \mathrm{P}<0.01 ; * *_{-} \mathrm{P}<0.001$ relative to the animals of the control group. 
In the course of the experiment, the MDA level decreased in the second group by $2.35 \mu \mathrm{mol} / \mathrm{l}$, in the control group, the MDA indicators remained at the level of the beginning of the experiment. The activity of ceruloplasmin increased in the 2nd group by $0.52 \mu \mathrm{mol} / \mathrm{l}$, in the control group the indicators remained at the level of the beginning of the experiment.

A significant decrease in the level of MDA, which shows the level of free radical oxidation, which characterizes the presence of oxidative stress, accompanied by a number of metabolic disorders, is explained by the presence of a wide range of biologically active compounds in our herbal remedies.

In parallel with the normalization of the indicators of free radical (peroxide) oxidation of lipids, a tendency to approach the physiological norm in hematological indicators has been established. Thus, Table 4, 5 shows the values of blood cells and hemoglobin approaching the reference value when using phytobiotics as adaptogens to an additional diet.

Table 5. Hematological parameters of blood of cows with additional administration of phytobiotics in LLC "MASLOVO"

\begin{tabular}{|c|c|c|c|c|}
\hline Groups & Indicators & Norm & $\begin{array}{c}\text { Before the injectoin of } \\
\text { phytopreparations }\end{array}$ & $\begin{array}{c}\text { After the injection of } \\
\text { phytopreparations }\end{array}$ \\
\hline \multirow{7}{*}{ Control group } & $\begin{array}{c}\text { Hemoglobin, } \\
\mathrm{g} / 1\end{array}$ & $\begin{array}{c}90- \\
120\end{array}$ & $102,42 \pm 1,62$ & $102,68 \pm 1,21$ \\
\cline { 2 - 5 } & $\begin{array}{c}\text { erythrocyte, } \\
10^{12} / 1\end{array}$ & $5-7,5$ & $5,31 \pm 0,08$ & $5,26 \pm 0,11$ \\
\cline { 2 - 5 } & $\begin{array}{c}\text { leukocyte, } \\
10^{9} / 1\end{array}$ & $6-10$ & $9,73 \pm 0,09$ & $9,92 \pm 0,06$ \\
\hline \multirow{3}{*}{ Cranberry + marsh cinquefoil) } & $\begin{array}{c}\text { Hemoglobin, } \\
\mathrm{g} / 1\end{array}$ & $90-$ \\
\cline { 2 - 5 } & $\begin{array}{c}\text { erythrocyte, } \\
10^{12} / 1\end{array}$ & $5-7,5$ & $102,48 \pm 1,38$ & $109,60 \pm 1,53$ \\
\cline { 2 - 6 } & $\begin{array}{c}\text { leukocyte, } \\
10^{9} / 1\end{array}$ & $6-10$ & $5,15 \pm 0,07$ & $5,48 \pm 0,05^{* *}$ \\
\hline
\end{tabular}

Note: $*_{-} \mathrm{P}<0.05 ; *_{-} \mathrm{P}<0.01 ; *_{*}^{*} *_{-} \mathrm{P}<0.001$ relative to the animals of the control group.

Each of the phytobiotics has a rich chemical composition.

Nettle leaves contain a significant amount of antioxidant vitamins: ascorbic acid $(229.38 \mathrm{mg} \%)$, vitamin E $(35 \mathrm{mg})$, carotene $(420 \mathrm{mg} / \mathrm{kg})$, vitamin D $(4 \%), \mathrm{K}(0.2 \%)$, as well as vitamins of groups B $(35 \mathrm{mg}$ of B1, $3 \mathrm{mg}$ of B2, $1.7 \mathrm{mg}$ of B3, $18 \mathrm{mg}$ of B4, $32 \mathrm{mg}$ of B5), formic, pantothenic and other organic acids, as well as lysine $(14.7 \mathrm{~g})$, methionine + cystine $(9.8 \mathrm{~g})$, tannins and protein substances, gums, glycosidurticin, phytoncides, proteins, sugars, macro- (calcium $(21.1 \mathrm{~g})$, phosphorus $(4.2 \mathrm{~g})$, magnesium $(8 \mathrm{~g})$, potassium $(37 \mathrm{~g})$, sodium ( $0.3 \mathrm{~g})$, chlorine $(3.5 \mathrm{~g})$, sulfur $(2.2 \mathrm{~g}))$ and trace elements (iron $(210 \mathrm{mg})$, copper $(11 \mathrm{mg})$, zinc $(60 \mathrm{mg})$, manganese $(30 \mathrm{mg})$, cobalt $(0.05 \mathrm{mg})$, iodine $(0.2 \mathrm{mg}))$ $[4,12]$.

Lecithin is a powerful antioxidant that prevents the formation of highly toxic free radicals in the body. With its deficiency, the effectiveness of the effect of drugs decreases [1]. Lecithin accelerates oxidative processes, improves the functioning of the brain and cardiovascular system. It promotes better assimilation of fat-soluble vitamins (A, D, E and $\mathrm{K}$ ), increases the body's resistance to toxic substances, etc. [23].

Sprouted wheat germ is a source of vitamin E, B vitamins, amino acids: valine, methionine, isoleucine, leucine, phenylalanine, tyrosine, treamine, serine, histidine, glycine, alanine, aspartic and glutamic acids, as well as micro- and macroelements: magnesium, phosphorus, potassium, sodium, calcium, copper, gallium, barium, strontium, iron, cobalt, zinc, manganese [8].
The polyphenolic complex of the cinquefoil is represented by flavonoids (viceonin, luteolin-7glycoside, hyperoside, hesperidin, dihydroquercetin, robinin), coumarins (umbelliferone), oxycinnamic acids (caffeic and chicorean). Among the polyphenolic compounds of the marsh cinquefoil, robinin, rutin, dihydroquercetin, and aspigenin prevail [17]. Polyphenols have powerful antioxidant effects.

The chemical composition of the marsh cinquefoil is dominated by the following organic acids: citric, tartaric and oxalic acids. The main amino acids of marsh cinquefoil are leucine, glutamic and aspartic acids. When studying the chemical composition of the cinquefoil, 28 macro- and microelements were found, the main of which were $\mathrm{Ca}, \mathrm{P}, \mathrm{Fe}, \mathrm{K}, \mathrm{Na}, \mathrm{Mn}, \mathrm{Mg}[2,6,17]$. The listed chemical compounds have a positive effect on metabolic processes, thereby increasing the adaptive capabilities of the body.

The mineral composition of the marsh cinquefoil is shown in Table 6.

Organic acids predominate in the chemical composition of cranberries. They are a kind of connecting link between carbohydrate, fat and protein metabolism in the body. The main share of organic acids in cranberries is represented by citric (up to $1.28 \mathrm{~g}$ per $100 \mathrm{~g}$ of fresh berries) and apple (up to $0.3 \mathrm{~g}$ per $100 \mathrm{~g}$ of fresh berries) acids.

Also, cranberries are rich in polyphenolic compounds, namely catechins, anthocyanins and bioflavonoids [16, 22]. 
Table 6. Mineral composition of marsh cinquefoil, $\mathrm{mg} \%$ [9]

\begin{tabular}{|c|c|c|c|c|c|}
\hline \multirow{2}{*}{$\begin{array}{l}\text { Ele } \\
\text { ment }\end{array}$} & \multicolumn{5}{|c|}{ Plant part } \\
\hline & $\mathrm{R}^{*}$ & $\mathrm{~S}$ & GS & $\mathrm{L}$ & I \\
\hline $\begin{array}{l}\text { Ash } \\
{[\%]}\end{array}$ & $\begin{array}{l}1.70 \pm 0 . \\
06\end{array}$ & $\begin{array}{l}2.24 \pm 0 \\
06\end{array}$ & $\begin{array}{l}5.07 \pm 0 . \\
07\end{array}$ & $\begin{array}{l}6.95 \pm 0 . \\
02\end{array}$ & $\begin{array}{l}7.18 \pm 0 . \\
05\end{array}$ \\
\hline $\mathrm{K}$ & $217 \pm 1$ & $343 \pm 13$ & $416 \pm 36$ & $200 \pm 10$ & $271 \pm 9$ \\
\hline $\mathrm{Ca}$ & $215 \pm 1$ & $299 \pm 1$ & $385 \pm 2$ & $421 \pm 21$ & $502 \pm 1$ \\
\hline $\mathrm{Mg}$ & $141 \pm 1$ & $181 \pm 1$ & $241 \pm 1$ & $156 \pm 7$ & $231 \pm 1$ \\
\hline $\mathrm{P}$ & $53 \pm 17$ & $85 \pm 1$ & $136 \pm 1$ & $132 \pm 6$ & $207 \pm 1$ \\
\hline $\mathrm{Na}$ & $\begin{array}{l}50.1 \pm \\
0.1\end{array}$ & $\begin{array}{l}69.9 \pm \\
0.1\end{array}$ & $\begin{array}{l}91.1 \pm \\
0.1\end{array}$ & $\begin{array}{l}43.0 \pm \\
0.2\end{array}$ & $\begin{array}{l}23.2 \pm \\
0.1\end{array}$ \\
\hline $\mathrm{Mn}$ & $9.5 \pm 0.1$ & $\begin{array}{l}11.7 \pm \\
0.1\end{array}$ & $\begin{array}{l}17.08 \pm \\
0.4\end{array}$ & $\begin{array}{l}19.2 \pm \\
0.9\end{array}$ & $\begin{array}{l}26.1 \pm \\
0.5\end{array}$ \\
\hline $\mathrm{Fe}$ & $5.9 \pm 0.1$ & $4.7 \pm 0.1$ & $4.9 \pm 0.1$ & $6.2 \pm 0.3$ & $8.3 \pm 0.2$ \\
\hline $\mathrm{Zn}$ & $\begin{array}{l}3.32 \pm 0 . \\
01\end{array}$ & $\begin{array}{l}3.67 \pm \\
0.02\end{array}$ & $\begin{array}{l}3.15 \pm \\
0.02\end{array}$ & $\begin{array}{l}2.60 \pm \\
0.01\end{array}$ & $\begin{array}{l}3.85 \pm \\
0.02\end{array}$ \\
\hline $\mathrm{Al}$ & $\begin{array}{l}1.79 \pm 0 . \\
01\end{array}$ & $\begin{array}{l}1.68 \pm \\
0.02\end{array}$ & $\begin{array}{l}1.95 \pm \\
0.04\end{array}$ & $\begin{array}{l}4.40 \pm \\
0.02\end{array}$ & $\begin{array}{l}4.38 \pm \\
0.04\end{array}$ \\
\hline $\mathrm{Sr}$ & $\begin{array}{l}2.53 \pm 0 . \\
02\end{array}$ & $\begin{array}{l}3.46 \pm \\
0.01\end{array}$ & $\begin{array}{l}4.02 \pm \\
0.08\end{array}$ & $\begin{array}{l}3.30 \pm \\
0.09\end{array}$ & $\begin{array}{l}3.04 \pm \\
0.01\end{array}$ \\
\hline $\mathrm{Ba}$ & $\begin{array}{l}0.501 \pm \\
0.001\end{array}$ & $\begin{array}{l}0.515 \pm \\
0.001\end{array}$ & $\begin{array}{l}0.516 \pm \\
0.002\end{array}$ & $\begin{array}{l}0.320 \pm \\
0.009\end{array}$ & $\begin{array}{l}1.174 \pm \\
0.002\end{array}$ \\
\hline$S$ & $\begin{array}{l}19.0 \pm 0 . \\
5\end{array}$ & $\begin{array}{l}25.8 \pm \\
0.3\end{array}$ & $\begin{array}{l}45.4 \pm \\
0.3\end{array}$ & $\begin{array}{l}37.1 \pm \\
0.9\end{array}$ & $\begin{array}{l}52.5 \pm \\
0.1\end{array}$ \\
\hline $\mathrm{Cd}$ & $\begin{array}{l}0.080 \pm \\
0.002\end{array}$ & $\begin{array}{l}0.071 \pm \\
0.001\end{array}$ & $\begin{array}{l}0.031 \pm \\
0.001\end{array}$ & $\begin{array}{l}0.030 \pm \\
0.001\end{array}$ & $\begin{array}{l}0.008 \pm \\
0.001\end{array}$ \\
\hline $\mathrm{Cr}$ & $\begin{array}{l}0.036 \pm \\
0.001\end{array}$ & $\begin{array}{l}0.044 \pm \\
0.001\end{array}$ & $\begin{array}{l}0.059 \pm \\
0.001\end{array}$ & $\begin{array}{l}0.053 \pm \\
0.003\end{array}$ & $\begin{array}{l}0.079 \pm \\
0.001\end{array}$ \\
\hline $\mathrm{Co}$ & $\begin{array}{l}0.006 \pm \\
0.001\end{array}$ & $\begin{array}{l}0.007 \pm \\
0.001\end{array}$ & $\begin{array}{l}0.007 \pm \\
0.001\end{array}$ & $\begin{array}{l}0.007 \pm \\
0.001\end{array}$ & $\begin{array}{l}0.017 \pm \\
0.001\end{array}$ \\
\hline $\mathrm{Li}$ & $\begin{array}{l}0.072 \pm \\
0.001\end{array}$ & $\begin{array}{l}0.105 \pm \\
0.001\end{array}$ & $\begin{array}{l}0.161 \pm \\
0.001\end{array}$ & $\begin{array}{l}0.128 \pm \\
0.006\end{array}$ & $\begin{array}{l}0.092 \pm \\
0.001\end{array}$ \\
\hline $\mathrm{Ni}$ & $\begin{array}{l}0.067 \pm \\
0.001\end{array}$ & $\begin{array}{l}0.058 \pm \\
0.001\end{array}$ & $\begin{array}{l}0.065 \pm \\
0.001\end{array}$ & $\begin{array}{l}0.057 \pm \\
0.002\end{array}$ & $\begin{array}{l}0.117 \pm \\
0.001\end{array}$ \\
\hline $\mathrm{Pb}$ & $\begin{array}{l}0.031 \pm \\
0.006\end{array}$ & $\begin{array}{l}0.029 \pm \\
0.001\end{array}$ & $\begin{array}{l}0.032 \pm \\
0.001\end{array}$ & $\begin{array}{l}0.030 \pm \\
0.001\end{array}$ & $\begin{array}{l}0.028 \pm \\
0.001\end{array}$ \\
\hline $\mathrm{Cl}^{-}$ & $27 \pm 2$ & $117 \pm 7$ & $442 \pm 27$ & $311 \pm 19$ & $146 \pm 8$ \\
\hline $\mathrm{NO}_{3}{ }^{-}$ & $65 \pm 8$ & $52 \pm 6$ & $5 \pm 1$ & $200 \pm 23$ & $187 \pm 22$ \\
\hline
\end{tabular}

Ascorbic acid, vitamins A, PP and group B are the main vitamins in cranberries. Most of the macro- and microelement composition of cranberries are potassium, sodium, calcium, magnesium, phosphorus, iron, copper and zinc [19].

Seeds of meadow clover contain vitamins A, C, E, as well as B vitamins, organic acids, sitosterols, glycosides [20]. Meadow clover contains phenolic compounds of about $3.78 \%$ of the weight of the absolute dry raw material, while the share of flavonoids (rutin, cinaroside and quercetin) accounts for $2.95 \%$ of the weight of the absolute dry raw material.

The main microelement composition of clover is represented by copper, selenium, calcium and chromium $[3,14]$.

The main active ingredient in licorice is glycerrhizin, a significant part of which is found in the roots (up to 23\%). This phytobiotic contains a large amount of organic acids: salicylic, sinapic, ferulic, caffeic, as well as coumarins and a large group of polyphenols [7, 8, 20].

The chemical composition of licorice also contains vitamins $\mathrm{C}$ and $\mathrm{B}$ group, silicon, calcium, iron and potassium. The listed chemical compounds determine the hepatoprotective, adaptogenic and antioxidant effect of the plant $[10,15,18]$.

\section{Conclusion}

Currently, when using industrial technologies in the livestock industry, it is especially valuable to obtain organic products without the use of antibiotics, pesticides, hormones and growth stimulants, genetically modified ingredients that are heterogeneous for animals and humans. However, it is almost impossible to purchase meat and dairy products for consumers without antibiotics, since the use of antibiotics in large industrial complexes is still the only way to save animals from mass diseases. Given that antibiotics are difficult to remove from the animal body, the consumer receives them with meat and milk. In the production of livestock products, its quality is determined by the feeding system. To obtain environmentally friendly products, you should use ecological feeds, preferably of your own production. At the same time, the use of vitamin and mineral supplements, which must be of natural origin, is required to maintain the physiological and biochemical status of animals, their health and increase productivity, and therefore the use of phytobiotics, which we provide, is relevant.

The basic mechanism of action of phytopreparations based on nettle, germinated sprouts of wheat, clover, licorice, marsh cinquefoil and cranberry in the correction and prevention of biochemical disorders caused by stress is inhibition of free radical oxidation and activation of endogenous antioxidants.

\section{References}

1. E. Abashkina, A. Mzhelsky AgroMarket, June, 31-32 (2013).

2. T.A. Azunova, G.A. Bikmulina, Ya.G. Razuvaeva, A.G. Mondodoev, V.B. Khobrakova, E.V. Ferubko Siberian Medical Journal, 2, 76-78, (2008).

3. V. Yu. Andreeva, G. I. Kalinkina, T. V. Poluektova, V. A. Gulyaeva Chemistry of vegetable raw materials, 1, 97-104 (2018).

4. R.R. Akhmedkhanova Chief zootechnician, 11, 57-61 (2004)

5. O.A. Bagno, O. N. Prokhorov, S.A. Shevchenko, A.I. Shevchenko, T.V. Dyadichkina Agricultural biology, 53(4), 687-697, (2018).

6. G.A. Bikmulina, Pharmacotherapeutic efficacy of dry extract of marsh cinquefoil in experimental glomerulonephritis: PhD Abstr. Dis, Ulan-Ude, (2008).

7. V.A. Blinov, E.A. Shapulina Animal Science, 1, 16-18 (2007) 
8. L.I. Butenko, L.V.Ligay, Fundamental research.. 4-5, 1128-1133 (2013).

9. S.V. Golubev, A.A. Efremov Chemistry of vegetable raw materials, 1, 105-109, (2012).

10. Kh. A. Dadaev, MA Sadyrova, D. Kh. Akilov Biology and integrative medicine, 1 (47), 250-263 (2021).

11. D.K. Duskaev, G.I. Levakhin, N.N. Dokina Animal husbandry and feed production. 3, 204214, (2020).

12. O.V. Zhurba, M. Ya. Dmitriev, Medicinal, poisonous and harmful plants (Moscow: KolosS, 2008)

13. V.G. Zaitsev Model systems of lipid peroxidation and their application to assess the antioxidant effect of drugs, PhD Diss. Volgograd, (2001)

14. N. V. Zaitseva, A. A. Grigorieva Symbol of Science, 8, 17-20 (2015).

15. I. D. Karomatov Actual problems of the humanities and natural sciences, 11-2, 230-235 (2013)

16. M.N. Lyutikova, E.Kh. Botirov Chemistry of vegetable raw materials. 2, 2-27 (2015).

17. E.V. Malyuk Pharmacognostic study of marsh cinquefoil herb: $\mathrm{PhD}$ diss. (Pyatigorsk, 2007)

18. T.S. Salikhova, T.K. Salikhov Science and technology of Kazakhstan, 2, 109-112, (2010)

19. A. G. Smirnov, N. V. Biryukova The scientific heritage, 66-1 (66), 14-18, (2021).

20. N.I. Yarovan, N.L. Gribanova, P. S. Bolkunov Materials of the All-Russian scientific-practical conference with international participation on topical problems in the field of biotechnology, Oryol April 30, (2019)

21. U. Bernabucci American Dairy Science Association, 85, 2173-2179, (2002)

22. G. Khomych, Y. Matsuk, Y. Naconechnaya, L. Medved Technology and ecvuipment of food production.6/11 (90), 59-65, (2017)

23. L. K. Mahan, S. Escott-Stump, eds Krause's food, nutrition, \& diet therapy ( Philadelphia. Saunders, 2004). 